\title{
Filosofis Ketuhanan dalam Konsep Islam Menuju ketauhidan
}

\author{
Wahyudin \\ IAIN Metro \\ wahyudin@gmail.com
}

\begin{abstract}
Abstrak
God does not require the properties and values in addition to his perfection but creatures need, hunger and depend on the form of terrain, terrain divinity and divinity to ride their Existence. The terrain is not intended space. If a creature receives Emission or God creature would be destroyed and perish. Divinity into solid closed protects Existence of creatures and save them. Existence is no closed is to protect God's creation barrier Existence by divinity is stable, true and eternal entity. Various views that want to change the core of the program (monotheism) divinity in Islam, both of which come from outside of Islam even among Islamic all in stagnation. Ness program agreed core issues, which distinguishes the way, the practice of worship, interpretation leads to divinity, giving rise to a prolonged polemics.
\end{abstract}

Keywords: Reality trasenden, Theory of Godhead, Deconstruction and causality.

\section{Pendahuluan}

Pola perkembangan dan kemajuan berpikir manusia senantiasa disertai wahyu yang sesuai dan dapat memecahkan problematika yang dihadapi kaum setiap rasul, sampai perkembangan itu mengalami kematangannya. Allah menghendaki agar risalah Muhammad saw muncul di dunia ini, maka diutuslah beliau saat manusia tengah mengalami kekosongan para rasul, untuk menyempurnakan "bangunan" saudara-saudara pendahulunya (para rasul) dengan Ketuhanan yang universal dan abadi, serta dengan kitab yang diturunkan kepadanya, yaitu Alquran.

Tuhan tidak memerlukan sifat-sifat dan nilai-nilai tambahan untuk kesempurnaan-Nya tetapi makhluk memerlukan, berhajat dan bergantung kepada medan wujud, medan ketuhanan dan sifat-sifat ketuhanan bagi menumpang kewujudan mereka. Medan tersebut bukan bermaksud ruang. Tidak boleh dikatakan di samping ruang yang diisi oleh kewujudan makhluk ada ruang yang menempatkan kewujudan sifat-sifat ketuhanan. Sifat ketuhanan atau pun urusan Tuhan tidak memerlukan ruang. Misalnya, sifat Ilmu dan kewujudan dalam Ilmu tidak memerlukan ruang untuk wujud. Makhluk memerlukan pemangkin, penyokong, hijab atau medan wujud yang bersifat ketuhanan bagi memelihara kewujudan makhluk itu agar menjadi benar, nyata, ada kesinambungan dan stabil. Sifat ketuhanan juga diperlukan oleh makhluk bagi melindungi mereka daripada tajalli Allah swt.

Hakikat realitas trasendent bersifat supra sekaligus intrakosmos, personal dan impersonal, lahut dan nashut, mahkluk dan Tuhan, sayang dan jahat, lenyap dan abadi, tampak dan abstrak dan sifat lainnya yang dikotomik. Bahwa 
manusia adalah tajalli atau cermin asma dan sifat-sifat realitas mutlak, cermin asma dan sifat-Nya yang beragam. Oleh sebab itu, eksistensi kosmos yang dikatakan sebagai penciptaan pada dasarnya adalah penyingkapan asma dan sifatNya yang azali. ${ }^{1}$

Jika makhluk menerima tajalli Allah s.w.t makhluk akan hancur dan hilang lenyap. Sifat-sifat ketuhanan menjadi hijab yang kukuh melindungi kewujudan makhluk dan menyelamatkan mereka. Kewujudan yang tidak ada hijab melindunginya adalah kewujudan ciptaan ahli silap mata. Ciptaan ahli silap mata tidak stabil, tidak benar dan tidak bertahan kewujudannya. Ciptaan Tuhan yang dihijabkan oleh sifat-sifat ketuhanan bersifat stabil, benar dan kekal kewujudannya sampai kepada akhirat. Hijab ketuhanan yang memegang kewujudan makhluk, yang ada hubungan dengan makhluk, itulah sifat-sifat Tuhan yang Dia izinkan dinisbahkan kepada-Nya. Sifat-sifat-Nya yang tidak boleh diperkatakan adalah sifat-Nya yang hakiki. Aspek Tuhan yang boleh disifatkan dan diperkatakan dinamakan tasybih dan yang tidak boleh dikatakan dinamakan tanzih. "Tiada sesuatu menyamai-Nya" adalah aspek tanzih. "dan Dia mendengar dan melihat" adalah aspek tasybih. Makrifat yang sempurna adalah yang mengenal Tuhan dalam aspek tasybih dan tanzih sekaligus.

Sebagaimana pendapat Al Kindi bahwa Tuhan adalah wujud yang hak (benar) yang bukan asalnya tidak ada kemudian menjadi ada. Ia selalu mustakhil tiada ada. Ia selalu ada dan akan selalu ada. Oleh karenannya Tuhan adalah wujud sempurna yang tidak di dahului oleh wujud lain, tidak berakhir wujudnya dan tidak ada wujud kecuali denganNya. ${ }^{2}$

Dengan menyimak pendapat Al kindi tersebut bahwa Tuhan adalah dzat yang menyiptakan alam semesta,yang maha kuasa dan mengatur segalanya tiada sesuatu yang menyerupainya dan dia tidak butuh kepada makhluknya.Tuhan adalah dzat yang Esa. Esa di maksud sudah menyangkup hal di atas, bukan hanya tertumpu kepada dzatnya sendiri.Tuhan tidaklah merasakan sakit seperti apa yang dirasakan makhluknya, dan tidak lapar serta tidak mengantuk dan lelah, karena hal itu semua ada karena diciptakan tuhan sebagai qadrat makhluq (Manusia, Jin dan Hewan) Dzat yang sudah menyangkup hal-hal di atas yang sudah disebutkan berarti pantas dikatakan tuhan.

Pengkaburan Sifat Tuhan dengan Makhluk, ada seseorang yang terbawa imijinasi yang terlalu tinggi dan memberikan sifat dan keadaan makhluk kepada tuhan seperti contoh: "Adakah Tuhan itu berkuasa untuk mencipta satu batu yang terlalu berat, yang tidak mampu diangkat oleh dirinya sendiri?" menunjukkan keinginan meletakkan sifat manusia kepada Tuhan. Berat adalah

1 Abdul Razak dan Dr.Rosihan Anwar, Ilmu Kalam untuk UIN, STAIN PTAIS (Bandung: Pustaka Setia, 2001) h. 36.

2 A. Hanafi, Pengantar Filsafat Islam, (Jakarta: Bulan Bintang, 1969) h. 85. 
hukum yang dicipta Tuhan, apa yang berat di bumi tidak berarti di angkasa. Berat tidak mengamal di alam ghaib, sedangkan tuhan sendiri itu kekuatannya/kemampuannya melampui segalanya dan penciptanya tiap-tiap sesuatu termasuk ruang angkasa dan dunia ghaib.

Pada era modern yang serba modern dan serba multitekhnologi sekarang pengayaan ketuhanan menyadi lebih ekstrim di sebabkan oleh kemajuan tingkat pemikiran manusia di iringi dengan kemajuan di bidang teknologi. Sehingga persoalan ketuhanan dalam ranah mikrokosmos bukan lagi sekedar ketauhidan semata akan tetapi merambah kepada tata cara pelaksanaan/ praktek dalam mentauhidan Allah Yang Maha Esa tersebut. Semua orang Islam sepakat tentang Ketauhidan Allah, juga orang kristen mengatakan tentang ketauhidan Allah bahkan Orientalispun demikian. Yang membedakan yakni pelaksanaan praktek ke-agama-an menuju KE-TAUHID-AN yang berbeda, disinilah timbul muara Theologi (Ketuhanan) kritik atas teologi.

\section{Pengertian Tuhan}

Tuhan (Ilah) ialah sesuatu yang dipentingkan (dianggap penting) oleh manusia sedemikian rupa, sehingga manusia merelakan dirinya dikuasai (didominir) olehnya (sesuatu itu). Perkataan "dipentingkan" hendaklah diartikan secara luas. Tercakup di dalamnya yang dipuja, dicintai, diagungkan, diharapharapkan dapat memberikan kemaslahatan atau kegembiraan, dan termasuk pula sesuatu yang ditakuti akan mendatangkan bahaya atau kerugian. Syaikhul Islam Ibnu Taimiyah memberikan definisi al ilah sebagai berikut:

Al-ilah ialah yang dipuja dengan penuh kecintaan hati; tunduk kepadanya, merendahkan diri di hadapannya, takut dan mengharapkannya, kepadanya tempat berpasrah ketika berada dalam kesulitan, berdo'a dan bertawakkal kepadanya untuk kemaslahatan diri, meminta perlindungan dari padanya, dan menimbulkan ketenangan di saat mengingatnya dan terpaut cinta kepadanya. ${ }^{3}$

Berdasarkan definisi ini dapatlah difahami, bahwa tuhan itu bisa berbentuk apa saja, yang dipentingkan oleh manusia. Yang pasti ialah manusia tidak mungkin atheist, tidak mungkin tidak bertuhan. Berdasarkan logika al-Qur'an bagi setiap manusia mesti ada sesuatu yang dipertuhankannya. Dengan demikian, maka orang-orang komunis itu pun pada hakikatnya bertuhan juga. Adapun tuhan mereka ialah ideology atau angan-angan (Utopia) mereka, yaitu terciptanya "masyarakat komunis, dan setiap orang boleh bekerja menurut kemampuan masing-masing dan mendapatkan penghasilan sesuai dengan kebutuhan masing-masing", sebagai yang dirumuskan dengan jelas oleh pemimpin mereka, Lenin, di dalam manifesto communisme-nya: "From everyone

3 Yusuf Qardawi: "Tauhid dan Fenomena Kemusyrikan, Haqiqat Al-Tauhid terjemahan H. Abd. Rahim Haris, (Jakarta: Pustaka Darul Hikmah, 2001), h. 26 
according to his ability, and for everyone according to his need." Ungkapan inilah yang diterjemahkan oleh para pemimpin mendiang PKI (Partai Komunis Indonesia) dahulu dengan slogan: "sama rata sama rasa". Orang komunis sebenarnya memimpikan terciptanya suatu masyarakat bertata ekonomi yang "adil sempurna". ${ }^{4}$

Sungguh suatu tanda tanya besar bagi setiap Muslim, yang yakin akan kesempurnaan kitab sucinya. Mungkinkah Allah telah "lupa" menyebutkan kenyataan ini, sehingga al-Qur'an tidak menyebut sama sekali akan atheist dan atheisme ini.

Q.S al-Insan: 30

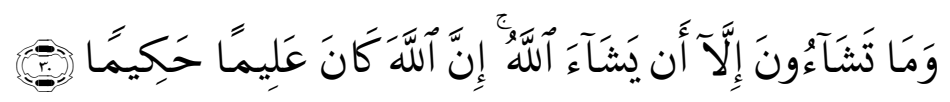

"Dan kamu tidak mampu (menempuh jalan itu), kecuali bila dikehendaki Allah. Sesungguhnya Allah adalah Maha mengetahui lagi Maha Bijaksana" .5

Perkataan "ilah", yang selalu diterjemahkan "tuhan". Di dalam al-Qur'an dipakai untuk menyatakan berbagai objek, yang dibesarkan atau dipentingkan manusia. Misalnya, di dalam ayat Q. 45:23 dan Q.25:43."Tidakkah kamu perhatikan betapa manusia meng-ilahkan keinginan-keinginan pribadi mereka.

Persepsi manusia tidak dapat mencapai pengetahuan yang memadai tentang sumber asli dari benda-benda masalahnya, adalah mengetahui asas mutlak identitas pemikiran dan keberadaan, asas ini adalah tuhan. Karena tuhan adalah satuan mutlak atau identitas pemikiran keberadaan. Tuhan adalah satuan tak beruang dan tak berwaktu, sedang dunia adalah suatu pluralitas ruang waktu. Agama bukan merupakan pembuktian rasional tindakan pemujaan dan hanya merupakan tindakan moral. ${ }^{6}$

Pemberian nama Tuhan dalam pemahaman orang di Indonesia yang beragama Islam dan Kristen, Tuhan biasa dipanggil dengan sebutan Allah. Kata tersebut berasal dari rumpun bahasa Arab yaitu berasal dari kata "al" yang sama artinya dengan "the" dalam bahasa Inggris dan kata "Illah" (Tuhan). Secara harfiah Allah berarti Tuhan yang satu dan pasti satu. Sedangkan dalam keyakinan penganut Hindu Tuhan di beri sebutan Brahma atau Sanghyang Widhi Wasa dan dalam literatur agama Budha Tuhan itu adalah Atthi Ajatan Abhutan AkatanAsam Khatan artinya suatu yang tidak dilahirkan, tidak di jelmakan, tidak diciptakan dan Yang mutlak. ${ }^{7}$

${ }^{4}$ Ibid, h 27

5 Departemen Agama Republik Indonesia, Alqur'an dan terjemahannya,(Jakarta: Yayasan penerjemah, 1974), h.1006

${ }^{6}$ Ali Mudhafir, Op Cite, h. 473 h. 46 .

7 Antonius Atosokhi Gea dkk, Relasi dengan Tuhan, (Jakarta: Elex Media Komputindo, 2004) 
Dengan demikian Tuhan itu tidak dapat dipersonifikasikan dan tidak dapat digambarkan dalam bentuk apapun, dengan adanya yang mutlak yang tak terkondisi, maka manusia yang berkondisi dapat mencapai kebebasan dari lingkaran kehidupannya yakni dengan cara bermeditasi. ${ }^{8}$

\section{Teori Ketuhanan}

Sebahagian orang ada yang menganggap dirinya sedemikiran pintarnya, sehingga ia merasa tak perlu bertuhan. Mereka mengatakan, bahwa mereka tidak perlu kepada sesuatu yang tak dapat dibuktikan. Merekapun menolak jika dikatakan atheist. Mereka menamakan diri mereka agnostic. Salah seorang tokoh orang-orang agnostic ini yang terkemuka ialah mendiang Bertrand Russel, ahli falsafah dari Inggris, yang pernah diundang dengan hormatnya untuk memberikan kuliah pada beberapa universitas di Amerika Serikat di awal tahun empat-puluhan. Kuliah-kuliah yang disampaikannya telah sempat menimbulkan kemarahan tokoh-tokoh Kristen Amerika, terutama Bishop Manning dari Gereja Episcopal, karena dianggap "sangat bertentangan dengan agama dan nilai-nilai moral". Memang Russel berpendirian, bahwa "semua agama yang ada didunia ini Budha, Hindu, Kristen, Islam, dan Komunisme " adalah palsu dan berbahaya" ("I think all the great religions of the world Buddhism, Hinduism, Christianity, Islam, and Communism both untrue and harmfull"), karena itu ia menentang semua agama. ${ }^{9}$

Sangat menarik perhatian ialah, sama dengan Toynbee, Russel pun menganggap komunisme sebagai agama. Kalau kita baca bukunya yang terkenal: "Why I Am Not a Christian" (Mengapa Saya Bukan Seorang Kristen), maka dapat dinyatakan, bahwa ia tokoh bertuhan juga. Russel, pada hakikatnya, telah mempertuhankan 'aqalnya. Selama ia bisa konsisten, sebenarnya masih lumayan, terutama jika dibandingkan dengan orang yang bertuhankan hawa nafsunya. Tetapi, mungkinkah seseorang senantiasa consistent.

Berdasarkan pengertian "ilah" atau tuhan yang telah diberikan definisinya di atas, maka dapat pula secara logika dibuktikan, bahwa tidak ada manusia yang mampu berfikir logis, yang tidak punya tuhan. Bahkan bisa dibuktikan, bahwa tidak mungkin bagi manusia tidak punya sesuatu kepercayaan. Apabila seseorang mengatakan: "saya tidak percaya kepada sesuatu apa pun," maka ia akan dihadapkan kepada suatu kontradiksi, karena pernyataan tersebut mengandung pembatalan diri. Jika benar ia tak pcrcaya kepada sesuatu apapun, maka kalimat itupun ia harus sangkal kebenarannya. Jika tidak, maka terbukti ia toh masih punya satu kepercayaan, yaitu kebenaran pernyataan tersebut, maka

8 Cornelis Wowor, Ketuhanan Yang Maha Esa dalam Agama Budha, (Jakarta: Akademi Buddhis Nalanda, 1984) h.1

9 Muhammad 'Imaduddin dan 'Abdulrahim, Kuliah Tauhid,Ir. (Bandung: PustakaPerpustakaan Salman ITB 1980) h. 7 
sikap itu bertentangan pula dengan arti kalimat itu. Jadi kalimat itu tidak logis, dan tidak mungkin terucapkan oleh seseorang yang mampu dan mau berfikir logis.

Menurut Pater Wilhem Schmidt yang pernah berkarya di Flores, Penghayatan ketuhanan dalam keagamaan aseli seluruh alam diresapi oleh kekuatan-kekutan ghaib yang tidak kelihatan, seperti banjir, kekeringan, orang kejatuhan pohon dimangsa binatang buas apapun yang menimpa manusia, mengungkapkan kekuatan-kekuatan tak kelihatan itu. ${ }^{10}$ Pandangan dunia jawa asali memahami alam sebagai berdimensi dua, dimensi lahir dan dimensi batin. Dimensi lahir merupakan alam kelihatan, akan tetapi alam kelihatan hanya dimengerti dari dimensi batin dari kekuaan-kekuaan yang ada di belakangnya. Penghayatan aseli ini adalah bahwa tidak ada pemisahan antara alam dan yang Ilahi.

Sebagaimana yang terjadi dalam agama Hindu walau ada banyak Tuhan nama yang diberikan, fenomena tersebut dalam kaitan fungsi dan tugas. Demikianlah Sanghyang Widhi disebut Brahma pada waktu penciptaan alam semesta dengan segala isinNya, disebut Wisnu pada waktu beliau memelihara semua ciptaanNya dengan penuh cinta kasih. Dan disebut Siwa pada waktu beliau mengembalikan segala ciptaanNya ke asalNya. ${ }^{11}$

Para filosofi Islam juga mengikuti konsepsi Aristoteles, yaitu bahwa Tuhan itu adalah zat yang berfikir dan menjadi obyek pemikiran-Nya (aqil dan $\left.m a^{\prime} q u l\right)$ karena zat-Nya sendiri. Namun Dia tidak mengakui adanya bilangan (pluralitas) pada-Nya dengan segala perintah-Nya. Para filosofi Islam menjelaskan hakikat Tuhan dengan uraian yang jelas. Menerangkan bahwa Dia adalah wujud yang pertama dan sebab yang sebenarnya bagi semua wujud dan peristiwanya, suci dari sekutu dan bandingan. Ia adalah Tuhan yang Maha Esa, hidup, berkuasa, Maha Mengetahui, Maha Bijaksana, dan Maha Mendengar. ${ }^{12}$

Tuhan menempatkan diri di atas gambaran dan gambaran mebangkitkan pemikiran Tuhan dalam diri si pemuja. Sepotong kertas putih biasa atau kertas berwarna biasa tidak memiliki nilai dan kita akan mencampakkannya. Kebangkitan ke-Tuhan-an bertindak seperti seorang malaikat penjaga yang memberkahi semuanya dan memberikan kebaikan yang tertinggi pada mereka yang sujud padanya.

Kamu dan aku adalah titik-titik pusat dari alam semesta. Tapi "Aku" itu adalah satu. Jadi tidak ada lagi "kamu" dan "aku". Tak ada lagi subyek dan obyek. Satu dan hanya satu ...atau "aku" dengan alam semesta. Teori mengenai alam semesta yang senantiasa bertambah luas (the expanding theory of the universe)

${ }^{10}$ Franz magnis suseno, Menalar tuhan, (Yogyakarta: Kanisius, 2006) h. 12

11 Cundamani, Bagaimana Umat Hindu Menghayati Ida Sanghyang Widhi, (Jakarta: Departmen Agama RI, 1990) h,11

12 Ahmad Daudy, Kuliah Filsafat Islam, (Jakarta: Bulan Bintang 1986) h, 162 
mengatakan bahwa setiap titik dalam alam semesta yang senantiasa memperluas adalah pusat dari alam semesta, setiap mahluk dalam alam semesta adalah focal point (titik pusat) dari mana alam semesta itu muncul.

\section{Dekonstruksi Ketuhanan}

Sebuah doktrin atau klaim kebenaran berusaha untuk membuatnya benarbenar valid dan bisa dipakai oleh zaman, namun hal itu tidak berjalan dengan sepenuhnya mulus, banyak tantangan, kritikan, dan hambatan meskipun tidak sedikit yang memberikan aplaus terhadap klaim kebenaran yang telah dibawanya dan kemudian mengikutinya dan menjadi eksponen setianya.Namun, pembentukan sebuah kebenaran tentu tidak mudah dan harus melalui sebuah rantai yang pada tataran praktisnya selalu abadi, melampaui ruang dan waktu. Rantai tersebut adalah representasi dari adanya bentuk falsifikasi yang terejawantah pada tesis-antitesis, aksi-reaksi dan konstruksirekonstruksi atau dekonstruksi, oleh karena itu kebenaran akan selalu menjadi kebenaran sementara (hypo-knowledge) yang suatu saat akan terfalsifikasi dalam bentuk yang beragam rupa sesuai dengan parameter dan indikator yang mengiringnya baik yang bersifat aksidensial, lokalitas, konstektualitas maupun karena sudah lemahnya jari-jari kebenaran tersebut mencengkram suatu zaman.

Mencermati anasir-anasir dekonstruksi atau rekontruksi tersebut sebuah metodologi akan mengulas tentang makna ketuhanan melalui program pengembangan riset bukan merubah inti program (pokok, dasar, azas) melainkan lingkaran pelindung berupa teori-teori pendukung. Dengan meminjam pendapat Imre Lakatos ada elemen yang harus diketahui dalam kaitan program riset:

1. Inti Pokok (Hard core), inti ini yang tidak dapat ditolak atau dimodifikasi.

2. Lingkaran pelindung (Protective belt) yang terdiri dari hipotesa-hipotesa Bantu (auxiliary hypothese), hipotesa pelindung ini harus menahan berbagai serangan, pengujian, dan memperoleh penyesuaian, bahkan perubahan dan pergantian demi mempertahankan inti pokok.

3. Serangkaian teori (a series theory) teori dimana teori berikutnya merupakan akibat dari klausal Bantu yang ditambahkan dari teori sebelumnya. ${ }^{13}$

Sebagaimana agama Islam memiliki ajaran pokok (ushul) dan ajaran pendukung (furu'). Sebagai contoh dari implementasi pendekatan program pengembangan riset Lakatos dalam Islam adalah konsep tauhid. Doktrin bahwa Allah itu Esa, tiada berbilang, dapat ditempatkan sebagai inti program. Sementara, lingkaran pelindungnya ayat-ayat Al Quran, hadist-hadist aqidah, teori kausalitas, teori "mungkin" dan "mustahil, teori fitrah, dan berbagai macam

${ }^{13}$ Muhammad Muslih, Filsafat Ilmu, kajian atas asumsi Dasar Paradigma dan Kerangka teori ilmu Pengetahuan, (Yogjakarta Belukar, 2006) h. 121 
teori lainnya. Program ini terus berkembang menjadi konsep Aqidah Islamiyah. Ketika ada serangan yang ingin menggugurkan program ini, maka langkah awal yang mesti dilakukan, meneliti keilmiahan dari teori penyerang. Jika tidak manjur maka lapisan pelindung akan siaga untuk "berperang".

\section{Dekonstruksi Teori Ketuhanan}

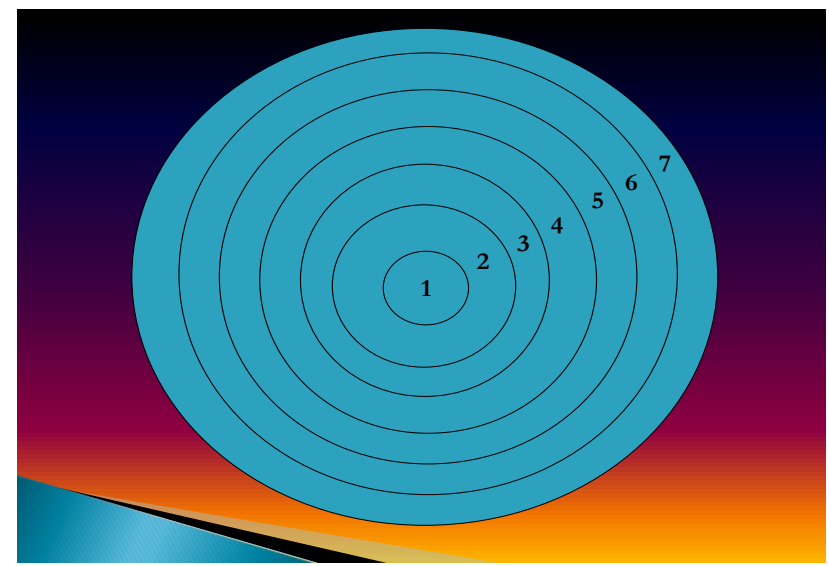

1. Inti Program / Doktrin (Konsep Tauhid) Allah itu Esa

2. Lingkaran Pelindung Ayat Alqur'an

3. Hadist-hadist

4. Teori Kausalitas

5. Teori Mungkin dan Mustakhil

6. Teori Fitrah

7. Teori relasi-dealektif.

Program pengembangan dekontruksi ketuhanan

1. Konsep Tauhid

Tauhid sebagai suatu pengetahuan kesaksian, keimanan, dan keyakinan terhadap keesaan Allah dengan segala kesempurnaan-Nya. Konsep tauhid karena membahas ke Esaan Allah Swt, didalamnya dikaji yakni tentang asma (nama-nama) dan af'al (perbuatan-perbuatan) Allah yang wajib, mustakhil dan ja'iz. ${ }^{14}$ Berdasar Al-Qur'an, keesaan Allah itu meliputi tiga hal, yaitu esa zat-Nya, tidak ada Tuhan lebih dari satu dan tidak ada sekutu bagi Allah; esa af'al-Nya, tidak ada seorang pun yang dapat melakukan pekerjaan yang dilakukan oleh Allah.

2. Lingkaran Pelindung yaitu; Ayat Alqur'an

Pernyataan yang terpenting dlam alqur'an adalah ke Esaan Allah yang mutlak. Allah memerintahkan segala sesuatu, baik yang besar maupun yang kecil. Alam semesta adalah rencana yang tunggal yang

${ }_{14}$ Abdul Razak, Ilmu Kalam, Op Cite, h,13

RI'AYAH, Vol. 02, No. 01 Januari-Juni 2017 
diciptakan oleh pengetahuannya dan kebijaksanaan dari pencipta dan penggerak yang tunggal. ${ }^{15}$

Tuhan Yang maha Esa, dengan demikian akan sealalu menumbuhkan, mengembangkan, mendidik, memelihara, menanggung, memperbaiki, mengumpulkan, mempersiapkan, memimpin, mengepalai, dan menyelesaikan. Dalam kaitannya dengan pembahasan ke Esaan dalam Alqur'an dapat dijelaskan bahwa yaitu zat yang menghidupkan dan mematikan.

3. Hadist-hadist

Diriwayatkan dari Jabir berkata,"Rasulullah saw bersabda,'Orang beriman itu bersikap ramah dan tidak ada kebaikan bagi seorang yang tidak bersikap ramah. Dan sebaik-baik manusia adalah orang yang paling bermanfaat bagi manusia." (HR. Thabrani dan Daruquthni

4. Teori Kausalitas (sebab Akibat)

Tuhan semata mata yang azali, sedang yang lainnya adalah baru dan dijadikan olehNya. Oleh karena itu, maka Tuhan adalah Zdat pencipta yang sebenarnya dan pergantian generasi merupakan penciptaan yang murni, dalam penciptaan tersebut Tuhan menjadikan tiap-tiap satunya dari tiada dengan secara langsung16

5. Teori Mungkin dan Mustakhil

Wujud yang mungkin atau wujud yang nyata karena lainnya (Wajibul ul wujud li Ghairihi) seperti wujud cahaya yang tidak akan ada kalau sekirannya tidak ada matahari. Cahaya itu sendiri menurut tabiatnya bisa wujud dan bisa tidak berwujud. Kalau ia tidak ada maka yang lainnyapun tidak akan ada sama sekali. Ia adalah sebab yang pertama bagi semua wujud. Wujud yang wajib tersebut dinmakan Tuhan (Allah). ${ }^{17}$

Menurut Osman Raliby, kemahaesaan Allah adalah: Allah Maha Esa dalam zat-Nya. KemahaEsaan Allah dalam zat-Nya dapat dirumuskan dengan kata-kata bahwa zat Allah tidak sama dan tidak dapat disamakan dengan apapun juga. Zat Allah tidak akan mati, tetapi akan kekal dan abadi. Allah juga bersifat wajibul wujud, artinya hanya Allah yang abadi dan kekal wujud-Nya. Selain Allah, semuanya bersifat mumkinul wujud, artinya boleh ada dan boleh tidak ada.

6. Teori Fitrah

Manusia merupakan mahluknya paling sempurna dan sebaikbaiknya ciptaan yang dilengkapi dengan akal fikiran. Ibn 'Arabi Dalam hal ini misalnya melukiskan hakikat manusia dengan mengatakan bahwa, "tak

15 M.Dawam Rahajo, Insanul Kamil Konsepsi Manusia menurut Islam, (Jakarta: Grafiti Pers,1987), h,75

${ }^{16}$ Hanafi, Op. cite, h 187

17 Ibid, h 98 
ada mahluk Allah yang lebih bagus daripada manusia, yang memiliki daya hidup, mengetahui, berkehendak, berbicara, melihat, mendengar, berfikir dan memutuskan. Harmonisasi kedua aspek tersebut dengan berbagai potensi yang dimilikinya menghantarkan manusia sebagai mahluk Allah yang unik dan istimewa, sempurna, dan memiliki deferensiasi. Dengan demikian bahwa secara fitrah manusia adalah mahkluk ciptaan Tuhan, jadi manusia itu berasal dan datang dari Tuhan ${ }^{18}$

7. Teori relasi-dealektif.

Visi filosofi dan antropologis yang dinukilkan Allah dalam al-Qur'an yang telah menduduki manusia dalam semesta ini ke dalam dua fungsi pokok, yaitu sebagai khalifa dan 'abd. Pandangan kategorikal demikian tidak mengisyaratkan suatu pengertian yang bercorak dualisme-dikotomik, tetapi menjelaskan muatan fungsional yang harus diemban manusia dalam melaksanakan tugas-tugas kesejarahan dalam kehidupannya di muka bumi. Dengan konsep khalifah, tidak di maksudkan untuk mempertentangkannya dengan konsep 'abd, melainkan keduanya harus diletakan sebagai suatu kesatuan yang tidak dapat dipisah-pisahkan. Keduanya memiliki relasi dialektik yang akan mengantarkan manusia kepad puncak eksistensi kemanusiaannya. ${ }^{19}$

\section{Analisis}

Perbagai pandangan yang ingin merubah inti program (ketauhidan) ketuhanan dalam Islam, baik itu Yahudi, Kristen, Hindu, Budha bahkan di kalangan dalam diri orang Islampun kesemunya mengalami kemandegan. Demikian pula dalam Islam sendiri permalahan inti program Ketauhidan sepakat, yang membedakan cara, proses bahkan, prakatek ibadah, interpretasi menuju kepada ketuhanan sehingga menimbulkan berbagai polemik yang berkepanjangan. Apakah itu di antara para ahli kalam (Theologi Islam), di kalangan tassauf, aliran aliran di dalam agama Islam, organisasi Islam (Muhammadiyah, Nu, LDII, Persis dll) baik Islam,fundamentalism, abangan, moderat, ortodok, kontemporer. Kesemua itu dalam rangka mentauhidkan kemahaEsaan yang berkembang dari zaman Rasulullah Saw hinga berkembang sampai detik ini. Serangan yang di lancarkan kepada Islam dalam kerangka memisahkan umat Islam dari kerangka ketauhidan, berbagai carapun dilakukan untuk membenamkan agama Islam dari muka bumi. Kalau agama Islam di perangi secara terang-terangan seluruh umat Islam akan bersatu padu untuk membela ketauhidan.

18 Ahmad Tafsir, Filsafat Pendidikan Islam, Integrasi Jasmani, rohani dan Kalbu memanusiakan manusia, (Bandung: Rosda Karya, 2010) h.14

19.Samsul Nizar, Filsafat pendidikan Islam Pendekatan Histori, Teoritis dan Praktis, (Jakarta: Ciputat Pers, 2002) h. 20 
Jika agama Islam sebagai agama rahmatalilalamin di perangi secara halus dalam rangka memisahkan ajaran ketauhidan dengan umatnya, maka kemungkian besar secara berangsur-angsur ketauhidan akan luntur dalam diri umat Islam. Fenomena tersebut sudah terasa di era sekarang melalui sebuah kebudayaan, bahwa budaya-budaya barat masuk kedunia umat Islam dengan cara yang tidak terasa, melalui budaya tersebut secara berangsur-angsur akan mempengaruhi dan memisahkan umat Islam dari ketauhidan.

Selama berabad-abad Islam dipandang sebagai orang lain dan musuh yang berbahaya bagi barat yang kristen. Edwar Said menegaskan bahwa " Bagi barat, Asia pernah dipandang sebagai suatu yang jauh dan asing, Islam sebagai musuh Barat agama kristen Eropa “. ${ }^{20}$ Barat yang kristen dengan konsep orientalisme bukan saja suatu doktrin positif mengenai timur yang selalu hadir di barat juga doktrin negatif, Orientalisme sebagai tradisi akademis yang sangat berpengaruh terhadap lapangan ilmu dan juga suatu kumpulan, gagasan-gagasan keyakinan, klise-klise atau pengetahuan mengenai timur dengan aliran-aliran pemikiran didalam kebudayaan.

Yang seharusnya diakui keberadaan orang-orang Oreientalis baik dari segi historis maupun filsafat bahwa beberapa diantara para Orientalis telah menghabiskan sebagaian umurnya kekuatan atau kemampuan mereka mempelajari Islam. Namun sangat disayangkan dalam kajian ilmiah itu (Orientalis), mencari kejelekan-kejelekan dan kelemahan Islam, kebudayaan Islam dan sejarah Islam yang sengaja mereka beberkan dalam kitab karangan mereka dan tujuan tertentu yang bersifat politik dan agama. ${ }^{21}$ Sebagaimana Renan seorang Perancis ia menyatakan akidah tauhid dalam Islam adalah akidah yang membingungkan dan merendahkan martabat manusia. ${ }^{22}$

Karakteristik orang-orang orientalis mempunyai visi dan misi serta inovasi, supaya umat Islam melepaskan ajaran agamanya dan memalingkan umat Islam dari ajaran itu, serta menginginkan keruntuhan keagungan agama Islam dari dunia. Adapun disisi lain sekalipun penulis-penulis orientalisme modern telah berusaha bersikap lebih sopan dan objektif dalam pendekatan terhadap Islam, nama-nama seperti Gibb, watt dan Smith. ${ }^{23}$

Doktrin (Ketauhidan) dalam agama Islam dibangun didunia sebagai tradisi agung bagi ideologi yang adil dan mulia, doktrin itu meniupkan kedalam diri manusia roh kedermawanan dan kemurahan disamping mudah melaksanakan dan mempunyai ciri-ciri kemanusiaan. Doktrin (Ketauhidan) Islam membentuk

${ }^{20}$ Mark R.Woodward, Jalan Baru Islam, (Bandung: Mizan, 1998) h. 29

${ }^{21}$ Bey Arifin, Islam Dan Para Orientalisme, (Surabaya: Bina Ilmu, 1983) h, 45

22 Muhammad Al Bahiy, Pemikiran Islam Modern, (Jakarta:Pustaka Panjimas 1986), h 4

23 Taufik Abdullah, Metodologi Penelitian Agama, (Jogjakarta: Tiara Wacana cet.ke 2 1990) h, 
masyarakat yang didalamnya jarang terdapat pemurtadan terhadap ketuhanan dan kekufuran seperti yang ada dalam masysarakat lain yang mendahuluimya.

\section{Kesimpulan}

Tuhan tidak memerlukan sifat-sifat dan nilai-nilai tambahan untuk kesempurnaan-Nya tetapi makhluk memerlukan, berhajat dan bergantung kepada medan wujud, medan ketuhanan dan sifat-sifat ketuhanan bagi menumpang kewujudan mereka. Medan tersebut tersebut bukan bermaksud ruang.

Al-ilah ialah: yang dipuja dengan penuh kecintaan hati; tunduk kepadanya, merendahkan diri di hadapannya, takut dan mengharapkannya, kepadanya tempat berpasrah ketika berada dalam kesulitan, berdo'a dan bertawakkal kepadanya untuk kemaslahatan diri, meminta perlindungan dari padanya, dan menimbulkan ketenangan di saat mengingatnya dan terpaut cinta kepadanya.

Tuhan menempatkan diri di atas gambaran dan gambaran mebangkitkan pemikiran Tuhan dalam diri si pemuja. Sepotong kertas putih biasa atau kertas berwarna biasa tidak memiliki nilai dan kita akan mencampakkannya. Kebangkitan ke-Tuhan-an bertindak seperti seorang malaikat penjaga yang memberkahi semuanya dan memberikan kebaikan yang tertinggi pada mereka yang sujud padanya.

Islam memiliki ajaran pokok (ushul) dan ajaran pendukung (furu'). Sebagai contoh dari implementasi pendekatan program pengembangan riset Lakatos dalam Islam adalah konsep tauhid. Doktrin bahwa Allah itu Esa, tiada berbilang, dapat ditempatkan sebagai inti program. Sementara, lingkaran pelindungnya ayat-ayat Al Quran, hadist-hadist aqidah, teori kausalitas, teori "mungkin" dan "mustahil, teori fitrah, dan berbagai macam teori lainnya

\section{Referensi}

Abdul Razak dan Rosihan Anwar. 2001. Ilmu Kalam untuk UIN, STAIN PTAIS. Bandung: Pustaka Setia

Ahmad Daudy. 1986. Kuliah Filsafat Islam. Jakarta: Bulan Bintang.

Ahmad Tafsir. 2010. Filsafat Pendidikan Islam, Integrasi Jasmani, rohani dan Kalbu memanusiakan manusia. Bandung: Rosda Karya.

Antonius Atosokhi Gea dkk. 2004. Relasi dengan Tuhan. Jakarta: Elex Media Komputindo.

Cornelis Wowor. 1984. Ketuhanan Yang Maha Esa dalam Agama Budha. Jakarta: Akademi Buddhis Nalanda.

Cundamani. 1990. Bagaimana Umat Hindu Menghayati Ida Sanghyang Widhi. Jakarta: Departmen Agama RI.

Dawam Rahajo M. 1987. Insanul Kamil Konsepsi Manusia menurut Islam. Jakarta: grafiti Pers.

Departemen Agama Republik Indonesia. 1974. Al-qur'an dan terjemahannya. Jakarta: Yayasan penerjemah 
Franz magnis suseno. 1969. Menalar tuhan. Yogyakarta: KanisiusHanafi. Pengantar Filsafat Islam. Jakarta: Bulan Bintang.

Mark R. Woodward. 1998. Jalan Baru Islam. Bandung: Mizan.

Muhammad 'Imaduddin dan 'Abdulrahim. 1980. Kuliah Tauhid. Bandung: Pustaka-Perpustakaan Salman ITB.

Muhammad Muslih. 2006. Filsafat Ilmu, kajian atas asumsi Dasar Paradigma dan Kerangka teori ilmu Pengetahuan. Yogjakarta: Belukar..

Samsul Nizar. 2002. Filsafat pendidikan Islam Pendekatan Histori, Teoritis dan Praktis. Jakarta: Ciputat Pers.

Yusuf Qardawi. 2001. Tauhid dan Fenomena Kemusyrikan, Haqiqat Al-Tauhid terjemahan H. Abd. Rahim Haris. Jakarta: Pustaka Darul Hikmah. 